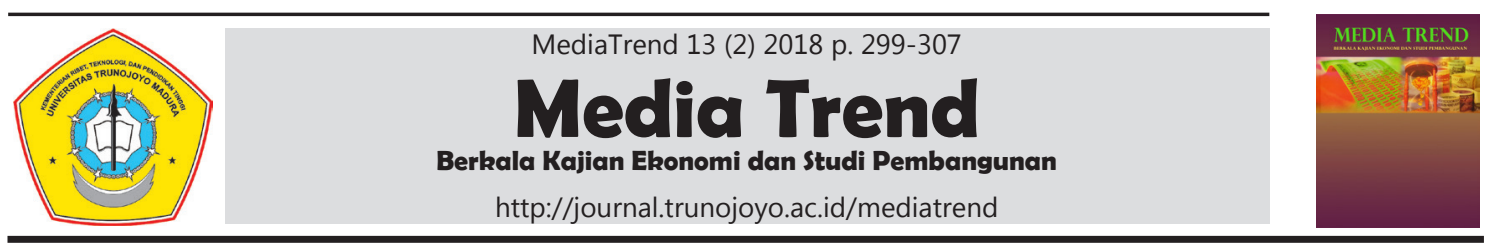

\title{
Regional Tax Externality and Competition: Empirical Study in Early De- centralization Era of East Java Province
}

\author{
Rifai Afin ${ }^{1^{*}}$ \\ ${ }^{1}$ Economics Department, Faculty of Economics, Trunojoyo University
}

\section{Informasi Artikel \\ Sejarah artikel: \\ Diterima September 2018 \\ Disetujui Oktober 2018 \\ Dipublikasikan Oktober 2018}

\section{Keywords:}

Fiscal Competition,

Tax Externalities,

Regional Development

\begin{abstract}
A B S TR ACT
This paper concerned with the empirical study about tax competition among regions which in a theoretical point of view, tax competition is seen as an economic policy strategy to attract mobile tax bases and firms in order to boost economic development in terms of employment and output growth within the political jurisdiction implementing it. Using a panel of more 400 observed district and municipal in East Java. It provides empirical evidence on how the local tax as well as the retribution in the neighborhood affect the local tax. The results support the existence of fiscal externalities: an increase in the tax and retribution of local neighbors exerts a positive effect on the local tax which is shown by spatial weighting variable both tax and retribution. Several factors that are hypothesized affect local tax also significant to determine local tax, these factors such as original regional income, and regional domestic product as a proxy of income.
\end{abstract}




\section{Introduction}

There are many questions around tax competition among neighboring jurisdictions have occupied economists for many years. Although early treatments of the issue were framed in the context of competition at the local level, it soon became clear that the analysis could be extended to tax competition among regions and even among nations with barriers to mobility and levels of economic integration becoming increasingly relevant as one moved from the local to the national level.

Early models of tax competition, developed by Wilson (1986) and Zodrow and Mieszkowski (1986), were based on Oates's (1972, p. 143) insight that, "In an attempt to keep taxes low to attract business investment, local officials may hold spending below those levels for which marginal benefits equal marginal cost." The basic source of the inefficiency in these models has been called a "horizontal tax externality:" a rise in one region's tax rate causes mobile capital to relocate to other regions, benefiting them because their tax bases contain this capital. This view of tax competition is not without controversy. In particular, there is now a literature on welfare-improving tax competition, much of it based on the notion that this competition leads governments to behave more efficiently than they would in its absence. See Wilson (1999) for a recent review of the various approaches to modeling tax competition.

Such a relatively big discrepancy on business taxation between sub-national governments provides a framework where tax competition and reduction of the tax burden should, theoretically, attract (or retain) firms within the jurisdiction implementing this policy. This should promote local economic development in terms of employment and output growth. In the literature it is further argued that tax competition is 'good' because: First, it limits public expenditure and thus the local power, since it cuts back on the revenues accruing from business taxation and hence curbs government spending; Second, it is an efficiencyenhancing policy that forces the general government sector to strive towards an optimal resource allocation.

Yet, some argue that tax competition is 'bad' because tax arrangements lead to the erosion of government revenues and may therefore put the sustainability of public spending at stake. This paper focuses on another, neglected issue, namely, that the dynamics of tax competition between sub-national governments is such that a local authority will not improve its relative position within the country and none will gain any long-lasting competitive advantages from such a policy, when considered from a closed-economy stance. In fact, when community a decides to cut corporate tax rates in order to gain a relative advantage on neighboring authorities, the latter will retaliate through decreasing their own taxation, so that any differential will be leveled out rapidly. In addition, the dynamics of tax competition between Indonesia sub national governments is such that all local authorities (district and municipal) could lose a part of their revenues from lowering taxation. This form of competition may eventually impinge on the implementation of the required, or planned, fiscal policies at the sub national level, where governments may indulge in granting ad hoc tax advantages to particular firms and/or their managers. This is so much so when a balanced budget requirement is taken into account. This paper try to investigate the relationship tax among regions which their own neighborhood.

The next section derives definition of tax competition and its externalities; we also try to explain about tax competition in prisoner dilemma in a stylized theoretical model. The third chapter describes the data available and a bit of its statistic description; mean and standard deviation. The impact of the neighborhood tax and also retribution revenue on the local tax and retribution was 
modeled in the next section in the econometric panel dynamic model with GLS technique. It yields a testable relationship between the local taxation, the tax both of district and municipal, and the retribution received by local government. The empirical section investigates this relationship using a panel of spatial tax and retribution weighting. After presenting the results, the implications for the local tax policy and the role of the tax revenue are discussed, followed by the conclusions in the section.

\section{Literature Survey \\ Defining Tax Competition}

To investigate the empirical evidence on tax competition, we first need a definition of tax competition. The literature on tax competition has devoted surprisingly little attention to defining this phenomenon. In some cases, tax competition seems to be defined very broadly as any form of non cooperative tax setting by independent governments.

A somewhat narrower definition adds the requirement that each government's tax policy influences the allocation of tax revenue across government treasuries. This requirement eliminates a broad class of models known as "yardstick competition." Rather than governments being linked through their treasuries, yardstick competition links them through the informational content of each other's tax policies. In particular, a comparison between taxes in a given jurisdiction and those in a "similar" jurisdiction enables voters in the former jurisdiction to assess the performance of current government officials and vote accordingly. There is nothing in this story about interdependencies between government budgets, and so we exclude it from this "broad definition" of tax competition.

For our narrowest definition, we narrow the reasons for why government budgets are interdependent. In particular, we define tax competition as non cooperative tax setting by independent governments, under which each government's policy choices influence the allocation of a mobile tax base among "regions" represented by these governments. In particular, governments may compete over the allocation of workers, firms, capital, or shoppers. This definition eliminates "vertical tax competition," where different levels of governments (e.g., federal, state, and local) impose taxes on the same tax base. Rather, it encompasses the large class of models known as "horizontal tax competition," under which governments at the same level are competing. We refer to this definition as the "narrow definition," or simply competition for mobile factors.

Our view is that the broadest definition encompasses too many phenomena to be of much interest. In fact, tax competition in this case would exist between two large trading economies that engage in tariff wars in an effort to manipulate their terms of trade in desirable ways. This is not what most researchers mean by "tax competition."

The broad definition seems overly broad, too, if we are to view the label "tax competition" to carry much descriptive power. In particular, in what sense are governments "competing" when engaged in yardstick competition? One answer is that they are competing over obtaining the informational advantages associated with being the low-tax region, but this seems quite different from competition over a mobile tax base. The welfare implications are also very different. It can be argued that "yardstick competition" improves welfare by disciplining government officials. On the other hand, it is widely thought that tax competition for mobile capital leads to inefficiently low tax rates.

Accordingly, the focus of this paper will on competition among independent governments over a mobile tax base. To keep the discussion manageable, we specifically focus on competition for mobile firms or factors (primarily capital), and do not deal with the sizable literature on com- 
modity tax competition or vertical tax competition.

\section{Tax Competition in a Prisoner's Dilem- ma Framework}

Tax competition may be considered as a regional (that is, cantonal) or local (i.e. communal) strategy implemented in order to 'bid for firms' (Wilson, 1999: 293-4). Decentralized fiscal authorities may seek to attract, or to retain, within their territorial jurisdiction the most interesting business activities for a number of macroeconomic reasons - basically, to enhance regional economic growth and development, as well as to curb unemployment. The underlying idea is that tax cuts create conditions that eventually enlarge the tax base so that there will be a net fiscal gain at the end of the process. This rationale provides some arguments for tolerating, or even promoting, tax competition between and within countries. From a theoretical perspective, the contention often raised in the literature is that tax competition constrains the Leviathan's appetite for more State power and more public money (Pommerehne, 1996; Feld, 1999). As a result, the general government sector is put under pressure to increase its public policies' efficiency, because competing governments have to carry out their spending plans with less tax revenues. In fact, this strategy may also help a country, improve, or consolidate, its competitive ranking with respect to the rest of the world. For the national economy as a whole this may have a positive effect on employment and economic growth.

\section{Dataset}

The dataset consists of the complete set of communities in East Java regions. It reports the revenues from taxes and another legal payment from the business tax as well as the level of grants and population on an annual basis from 1995 until 2005, which result more than 400 observations. These data were obtained from Central Bureau of Statistic ( Badan Pusat Statistik Jawa Timur) for East Java Regions. In the period under investigation the business tax precisely consisted of a combination of two taxes, one levied on business earnings the other levied on business capital. As the definition of taxable business earnings not only includes profits but also a major part of interest payments, the tax on business earnings can be regarded as a capital income tax. Unfortunately the local revenues derived from the two sources are not reported separately. Only at the national level information is available. Because of this problem we did not analyze kinds of sources tax separately. We use total tax revenue to proxy tax burden in each regions. In the table below, presented descriptive statistic for each variable included in this paper. Table 1 shows us mean and variance each variable from the total observation and in the table 3.2 shows us mean and variance each region and each variable. From table 2 we can see that the highest mean dominated by urban areas such as kota Kediri and Surabaya.

Tabel 1

Descriptive Statistic of Variables

\begin{tabular}{lrr}
\hline Variable & average & \multicolumn{1}{c}{ stdev } \\
\hline GDP & 3349785 & 6445882 \\
PAD & 85701.95 & 1370451 \\
TAX & 20117.04 & 252476 \\
RET & 36379.95 & 598133.6 \\
EXP & 63676.71 & 62230.19 \\
WTAX & 34155.17 & 212636.9 \\
WRET & 61256.68 & 501515.5 \\
DEF & -22025.2 & 1370232 \\
\hline
\end{tabular}


Regional Tax Externality....... MediaTrend 13 (2) 2018 p.299-307

Tabel 2

Descriptive Statistic of Variables in Each Region 1995-2005

\begin{tabular}{|c|c|c|c|c|c|c|c|c|}
\hline \multirow[t]{2}{*}{ REGION } & \multicolumn{2}{|c|}{ GDP } & \multicolumn{2}{|c|}{ PAD } & \multicolumn{2}{|c|}{ TAX } & \multicolumn{2}{|c|}{ RET } \\
\hline & Mean & Stdev & Mean & Stdev & Mean & Stdev & Mean & Stdev \\
\hline Pacitan & 605959.8 & 393069.4 & 1785.25 & 1934.556 & 58916.31 & 38536.45 & 4161.841 & 3760.434 \\
\hline Ponorogo & 1263611 & 843771.8 & 2807.859 & 2546.543 & 65626.87 & 35700.94 & 5425.937 & 3966.538 \\
\hline Trenggalek & 1048253 & 556105.1 & 1923.101 & 1412.105 & 59717.14 & 25223 & 7268.876 & 5923.857 \\
\hline Tulungagung & 2978153 & 2233671 & 4404.541 & 3249.035 & 54614.71 & 32440.98 & 6554.565 & 4706.305 \\
\hline Blitar & 2435455 & 1554042 & 3263.318 & 2666.11 & 55527.56 & 49824.14 & 8251.884 & 5280.486 \\
\hline Kediri & 2983611 & 1615544 & 5743.568 & 3825.316 & 84651.19 & 40379.14 & 8356.447 & 6036.173 \\
\hline Malang & 5952012 & 4089807 & 11574.28 & 8897.534 & 91605.09 & 66752.34 & 8024.241 & 4905.023 \\
\hline Lumajang & 2446083 & 1557859 & 4055.297 & 2638.736 & 56512.64 & 36612.69 & 8382.708 & 4680.212 \\
\hline Jember & 4550794 & 2857454 & 7350.721 & 4353.13 & 97031.54 & 65977.04 & 7162.556 & \\
\hline Banyuwangi & 4175388 & 3098578 & 6124.004 & 4840.116 & 60591.15 & 53828.54 & 9208.882 & 461 \\
\hline Bondowoso & 1071600 & 531612.9 & 1847 & 112 & 02 & & & \\
\hline Situbondo & 1632745 & 828297.1 & 3534.815 & 3212.131 & 54161.77 & 34025.88 & 6744.275 & 400 \\
\hline Probc & 2905 & 1779709 & 35 & 186 & & & & 47 \\
\hline Pasul & 3110 & 401 & 178 & 137 & 100 & 487 & 189 & \\
\hline Sidoarjo & 10447885 & 8088424 & 28749.16 & 24870.33 & 92517 & & & \\
\hline Mojokerto & 2566784 & 1546169 & 8966.89 & 6164.705 & 61676.14 & 42386.02 & 19281.76 & 140 \\
\hline Jombang & 2566421 & & 5863.363 & & & & & \\
\hline Ngar & 2080804 & 1238 & 3106.226 & 207 & 94 & 3475 & & 94 \\
\hline Madiun & 19026 & 744143.1 & 2355.419 & & 489 & 268 & 318 & \\
\hline Magetan & 60 & 885 & 2287 & 64 & 450 & 277 & 484 & \\
\hline Ngawi & 1393428 & 786415.8 & 2602.495 & 1818.747 & 51376.09 & 28893.87 & 565909.2 & 1860822 \\
\hline Bojoneg & 2445819 & 1673739 & 485011.2 & & & 29573.74 & 6811.568 & 4549.765 \\
\hline Tuban & & & & & & & & \\
\hline Lamong & 2396919 & 1254236 & 4847.502 & 3133.893 & 63421.63 & 3167 & 212347.7 & 6671 \\
\hline Gresik & 6393256 & 4158094 & 17121.16 & 15415.79 & 58005.68 & 32633.39 & 59233.85 & 34373.14 \\
\hline Bangkal & 1520858 & 924935.7 & & 3187.551 & 52569.31 & 22306.46 & 60435.44 & \\
\hline Sampang & 1185348 & & & 331 & 625 & 360 & & 3158.127 \\
\hline Pamekasan & 998307.5 & 504980.2 & 1918.157 & 1604.953 & 52034.08 & 23703.17 & 4032.386 & 3072.648 \\
\hline Sumenep & 2747914 & 1706264 & 1978.841 & 1858.338 & 166544.8 & 143353.6 & 4501.776 & 2533.535 \\
\hline Kota Kediri & 10827808 & 7084800 & 3389.261 & 2764.482 & 35321.36 & 19036.2 & 8256.623 & 5877.706 \\
\hline Kota Blitar & 519159.4 & 597816.2 & 2472.926 & 2838.323 & 28115.23 & 22032.34 & 5783.684 & 5161.005 \\
\hline Kota Malan & 5288943 & 3751562 & 12284.75 & 10090.5 & 45565.3 & 30695.34 & 7939.276 & 4786.164 \\
\hline Kota Probolingg & 831100.9 & 494137.7 & 2182.052 & 1496.758 & 23017.42 & 12993.43 & 3662.435 & 1904.195 \\
\hline Kota Pasuruan & 492320.8 & 268374.3 & 1874.131 & 1329.616 & 32515.51 & 18229.57 & 7228.935 & 4816.982 \\
\hline Kota Mojokerto & 509296.4 & 3210 & & & 30590.43 & & 7124.82 & 5089.248 \\
\hline Kota Madiun & 1713233 & 3863850 & 6523.465 & 11825.57 & 53748.35 & 51167.56 & 4193.134 & 2605.906 \\
\hline Kota Surabaya & 32164754 & 20689412 & 115581.3 & 86596.35 & 275754.3 & 150572 & 18378.03 & 13439.11 \\
\hline
\end{tabular}

Econometric Model and Variable Definition

The empirical model we introduce in this section closely follows the literature (Thiess Buettner, 2001) by including lag tax and spatial weighting scheme but in this paper we use common weighting technique in statistics. Tax rate and tax base on business sector as used by Thiess can not be applied in this time because the availa- bility of the data and then it was replaced by the total aggregate taxes data. In this paper we try to include regional gross domestic product (RGDP), retribution (RET), and deficit (DEF) between original regional incomes (PAD). Retribution and taxes denoted with bar represent the local neighborhood using spatial weighting. The general econometric model we use as follows: 


$$
\begin{aligned}
& T A X_{i}=\beta_{0 i}+\sum_{l=1}^{m} \beta 1_{l, t} \overline{\operatorname{TAX}}_{l, T-L}+\sum_{l=1}^{m} \beta 2_{l, t} \overline{\operatorname{RET}}_{i, t-l-}+\sum_{l=1}^{m} \beta 3_{i, t,} D E F_{i, t-l}+ \\
& \sum_{l=l}^{m} \beta 4_{l, t} P A D_{i, l-l}+\sum_{l=1}^{m} \beta 5_{l, l} R G D P_{i, l-t}+\psi_{t} f_{i}+\varepsilon_{i, t}
\end{aligned}
$$

Where TAX denoted the tax revenue as observed in region i in period t. DEF denoted regional budget deficit that can be obtained by computing differences between PAD (original regional income) and total expenditure in each region. RGDP denoted regional gross domestic product that reflects regional economic activity. wfi is the unobserved individual effect. Tax and retribution revenues denoted with a bar represent averages across the local neighbor-hood using a spatial weighting scheme (see above). As tax rates are set in advance and grants only react with a time lag to the current revenues simultaneity might be less of problem. Nevertheless, all explanatory variables on the right hand side are lagged, because the current tax obligation depends on income in the previous year.

The basic difficulty in estimating the influence of determinants of the business tax base is to ascertain a possibly lagged response in the tax base in the rather fluctuating measure of the tax base available to this study. A full representation of the underlying dynamics seems difficult given a dataset with observations for only 11 years. However, the recent literature on panel data estimation has developed procedures aimed at improving the quality of the empirical representation of dynamic processes. In order to take account of unobserved heterogeneity individual effects should be allowed for, which-In the current context -would pick up the given locational characteristics determining the attractiveness as a business location. They also pickup the basic cross sectional correlation between the jurisdictions (Case, 1991). Whereas the tax base of the business tax fluctuates with the business cycle the tax rates display a rather gradual trend. Therefore, it seems difficult to assume constant slope parameters, a\{priori, and, it may be that even the variance of the cross\{sectional distribution picked up by the individual effects is not constant over time.

\section{Estimation Results}

In this section we discuss our main results. Table 3 reports the main GLS regression results for model (1), using all observations for the period 1995-2005. In column (1) we note dependent variable which is Tax and dependent variables which are RGDP, PAD, RET, WTAX, WRET, and their first lag. While column (2) describes coefficients or parameters of independent variables, column (3) and (4) shows us error standard and $P$ value.

Table 3 displays the results. It shows that the sum of the structural coefficients generally has the expected sign but lag of each variable has opposite sign. The neighbors' taxes have impact, which is significant in all years, indicating the presence of fiscal neighborhood externalities; this can be seen in the sign of WTAX and WRET variable but there is an opposite sign; WTAX has a positive sign and WRET has negative sign. In the other view, we see that the lag of WTAX has negative impact in affecting tax. It can be understood as a reaction of the region which is caused taxation of their neighbors in previous year and it can be hypothesized asymmetric information occurs among regions. RGDP has positive impact on tax; it is well known in macro economic framework that income will increase tax revenue even though in the fixed tax rate. In the rule of summation of the parameter of each variable and its own lag $(\Sigma)$, tax and retribution has a negative impact. It means that increasing tax burden in the neighborhood will decrease tax burden in each regions over 1995-2005. 
Tabel 3

Estimation Result

\begin{tabular}{|c|c|c|}
\hline Variable & \multirow{3}{*}{ Coef. } & \multirow{3}{*}{ Std. Err. } \\
\hline Independent Variable & & \\
\hline TAX & & \\
\hline \multicolumn{3}{|l|}{ Dependent Variable } \\
\hline GDP & $0.000903^{*}$ & $9.52 \mathrm{E}-05$ \\
\hline PAD & $0.39372^{*}$ & 0.0323 \\
\hline RET & $-0.41059^{*}$ & 0.074106 \\
\hline WTAX & $0.080539^{*}$ & 0.029539 \\
\hline WRET & $-0.03386^{*}$ & 0.012442 \\
\hline DEF & $0.030793^{\star}$ & 0.004199 \\
\hline GDP1 & $-0.00052^{*}$ & 0.000112 \\
\hline PAD1 & $-0.25834^{*}$ & 0.040196 \\
\hline TAX1 & $0.863819^{*}$ & 0.03378 \\
\hline RET1 & $0.155874^{\star \star \star *}$ & 0.086704 \\
\hline WTAX & $-0.08849^{\star *}$ & 0.036043 \\
\hline WRET1 & $0.0375^{\star *}$ & 0.015174 \\
\hline DEF1 & $-0.03159^{*}$ & 0.00462 \\
\hline cons & $-683.001^{*}$ & 309.0852 \\
\hline
\end{tabular}

The original regional income (PAD) has positive impact on tax revenue but its lag has negative impact. Tax revenue is main resource of PAD so that it is easy to understand why PAD has positive impact but the negative impact of PAD can be understood as increasing PAD in the previous year will attract the region to decreasing tax income in the next year to give an incentive economic agent to gain on their business and live.

Retribution (RET) has negative effect on taxes. Retribution is a kind of fiscal instrument which can not only substitute part of the role of tax but also as a complement of the tax. Current year retributions conduct as substitution as part of tax revenue but the previous year of retribution conducts as complement. Regions will have targeted their income per year and if they can fulfill their target they will not attract to increase the tax revenue and its resources.

DEF significantly affect the tax. DEF reflects the lack of income and expenditure in each region. When DEF more than previous it will attract regions to try minimize their deficit even though central government give a help for this situation by general allocation fund for fiscal equalization grant. But this grant will not make local government try to increase their regional income. Nowadays, DEF and PAD have been a pride of local government and as a symbol of local government achievement and performance

\section{Conclusion}

This paper is the first to investigate whether there is tax and retribution externality or competition or not among regions in East Java except Batu. Tax Revenue and retribution were used as a proxy of burden to live and doing business in some regions in East Java. It can be predicted that the result will show significant impact of neighborhood fiscal policy such as tax and retribution. We found evidence of regional tax competition among regions both district and municipal. The spatial impact indicators, those are WTAX and WRET affect other regions which have spatial inter- 
action. In addition, we found that original regional income, deficit between original regional income and total expenditure, and also retribution have significant impact on tax.

On the theoretical framework, the lack of cooperation in direct taxation between sub national governments as well as tax competition is overall detrimental for the general government sector unless the goal of such a policy is to yoke the Leviathan. This kind of competition alters resource allocation and may reduce social welfare. Moreover, on the assumptions of unchanged policies and a balanced budget requirement, any tax bonus granted to a firm (or to a targeted group of firms) is bound to be compensated by an increased tax burden for other firms or individuals. This compensation introduces a system of implicit grants that threaten fiscal justice. To avoid these shortcomings, two proposals may be put forward at the policy level, one concerning tax competition as such and the other addressing the problem of asymmetric information within that framework. This attention to this problem need to be addressed and province government can do act coordination and maintain the productive competition among its territories.

\section{References}

Allers, MA and JP Elhorst (2005), 'Tax mimicking and yardstick competition among local governments in the Netherlands', International tax and public finance,

Besley, T. and A. Case (1995), 'Incumbent Behavior: Vote-Seeking, Tax-Setting, and Yardstick Competition', American Economic Review.

Badan Pusat Statistic (BPS).(2007). Produk Domestic Bruto Kabupaten/ Kota se-Indonesia 1994-2005". Laporan Tahunan BPS, Jakarta
Brett, C. and J.Prinske (2000), 'the determinants of municipal tax rates in British Columbia', The Canadian Journal of Economics

Brueckner, J.K. (2003), 'Strategic Interaction among Governments: An Overview of Empirical Studies', International Regional Science Review.

Buettner, T. (2001), 'Local business taxation and competition for capital: the choice of the tax rate', Regional Science and Urban Economics

Buettner, Thiess. (2001). "Fiscal Externalities in Local Tax Competition: Empirical Evidence from a Panel of German Jurisdictions". Martin School of Public Policy and Administration, University of Kentucky

Case, A., J.R. Hines and H.S. Rosen (1989), 'Copycatting: fiscal policies of states and the neighbors', NBER Working paper no 3032, Cambridge MA: National Bureau of Economic Research.

Desai, Mihir A., C. Fritz Foley, James R. Hines Jr. (2002). "Chains of Ownership, Regional Tax Competition, and Foreign Direct Investment". Michigan

Departemen Keuangan (DepKeu). (2007). Anggaran Pendapatan dan Belanja Daerah Kabupaten/Kota se-Indonesia; Realisasi dan Rencana (1994-2006). Sistem Informasi Keuangan Daerah, Jakarta.

Geys, B. (2006), 'Looking across borders: a test of spatial policy interdependence using local government efficiency ratings', Journal of Urban Economics

Justman Moshe, Jacques-Francois Thisse andTanguy van Ypersele. 2001. "Fiscal Competition and Regional Differentiation". The University of Namur, CREW and CORE, Belgium. 
Marlow, L Michael. (1995). " Public Finance: Theory and Practice”. Harcourt Brace \& Company, USA.

Rossen, Harvey S. (1999). "Public Finance”. Fifth edition. Mac Graw-Hill. USA

Rossi, Sergio and Bernard Dafflon. (2004). Tax competition between sub national governments: theoretical and regional policy issues with reference to Switzerland". University of Fribourg, Switzerland

Stata Reference.(2003). "Stata Reference; Statistic, Graphics, Data Management". Stata Corporation. USA

Vandenbussche,Hylke, Boudewijn Janssen and Karen Crabbé. 2004." Is there Regional Tax Competition in Belgium?" .LICOS Centre for Transition Economics, Discussion Paper 145/2004, Belgium

Wilson, John D. (2005). "Tax Competition in Federal Setting". Department of Economics, Michigan State University, East Lansing 